\title{
What Would Les Back Do? If Generosity Could Save Us
}

\author{
Rosalind Gill ${ }^{1}$
}

Published online: 17 July 2017

(C) The Author(s) 2017. This article is an open access publication

\section{Introduction}

Fifteen years ago, my beloved father died quite suddenly. Grieving and in shock, I accepted the paltry few days leave which constitute official "compassion" within British universities, posting an emotional out of office reply on my email to explain my absence from work. Two days later, a parcel bearing unfamiliar handwriting arrived for me at home. It was from Les Back. He had heard about my loss, he said, and he wanted to share a book that had touched and comforted him at a similar time. The book was Tuesdays with Morrie by Mitch Albom (1998), and I have subsequently discovered that it is one of Les's favourite books. It tells of a teacher-who, in Les's words, just "happens to be a sociologist"—as he confronts his imminent death from a debilitating illness. Rather than turning inwards or retreating from the world, Morrie finds a way to offer wisdom and insights in the face of death in one last "course" of tutorials with his friend and former student, Mitch. The book is by that "student." Writing about it in Academic Diary, Les comments: "This book is not about a dying man; it is about how to live. I think it is almost impossible not to love it." (2016: 126).

All these years on I still think about Tuesdays with Morrie, but, much more often, I recall not the book itself but the generous impulse that made Les send it to me- someone he knew very little. It remains one of my most moving memories of that time - my personal entry into what novelist Jane Smiley (1987) has called "the age of grief", a profoundly cherished gift amongst many other kindnesses.

I begin with this story because I think it captures something about Les Back's generosity, his care and his humanity, all of which pulsate through the pages of Academic Diary. Les's enthusiasm, his desire to connect with others and to share his passions, animate every single

An author's reply to this comment is available at doi:10.1007/s10767-017-9264-8

Rosalind Gill

Rosalind.Gill.2@city.ac.uk 
entry, including one where he discusses Tuesdays with Morrie as an example of his need to share books that he loves: "If a book really strikes a chord with me," he explains, "I feel like I need to give it to everyone who might appreciate the book in the same way" (2016:123). It might not be good for the bank balance, he adds wryly, but it is less of a choice and more of a compulsion - one that other bibliophiles will recognize. It springs from a personal ethics rooted in generosity and hope and sociability. What is striking is that this is not developed from a set of abstract precepts or propositions but seems to spring (if you will forgive the unsociological turn of phrase) from the very fibre of Les's being. Many of us - perhaps mostare passionate about our work, seeing it as an expression of deeply held aspects of our self, and wanting it to make a contribution to a better world. In Academic Diary, the entanglement between self and work is so intimate that it makes no sense to separate them at all.

\section{Reading the Crisis}

Academic Diary is a big, important, and visionary book, masquerading as something much smaller. It is just a blog, we are told; many other people made it possible; it is really only something to dip into when you have not got anything better to do. With characteristic modesty and humility, Les Back concludes the book explaining, "The entries are short because I imagine you will read them in a similar way, in transit, or in a calm moment over a cup of tea or coffee, squeezed in between the gaps of more pressing commitments."

I read Academic Diary in two sittings over a summer weekend. It wasn't squeezed in between more important things because reading it felt to me amongst the most important things I needed to be doing. After all, if we as sociologists cannot think about, engage with, and intervene critically against the destructive transformation of our own institutions, then what on earth are we doing? What are we for? How will we be judged when, in a few years time, our precious Universities are privatized, when the fees are so high that only the richest can afford to study in them, when students from elsewhere in the world are treated like suspects and terrorists (and it is "our" job to report on them), when the vast majority of academics constitute a huge underpaid precariat, when our curriculums are not only not decolonized but are recolonized by the interests of business and governments interested only in wealth creation? This is not some futuristic Brave New World. It is happening right here and right now and feels even more frightening with Brexit. If we are not going to stand up for a different vision of a University, then who will?

There are a growing number of books that attempt to "diagnose" the crisis of contemporary Universities (Evans 2004; Collini 2012). Some speak of the "edu factory" (Edu-Factory Collective 2009; Roggero 2011) or "the University in ruins" (Readings 1996); others of "academic capitalism" (Slaughter and Leslie 1997); still others document the horrors wrought by "new public management" (Lorenz 2012; Shore 2008; Halffman and Radder 2015), performativity (Ball 2000; Blackmore and Sachs 2000), or "neoliberalism" (Gill, 2010); or indict the marketization and corporatization of academia (Barcan 2013). Some highlight the catastrophic effects of student fees and debt (Ross, 2014); others condemn casualization and precariousness (SIGJ2 2012; Adsit et al. 2015; Nash and Owens 2015; Luka et al. 2015; Murgia and Poggio 2010); a few document the profound intersectional inequalities that still marginalize and exclude black, queer, and female scholars (Gutiérrez y et al. 2012; Bailey and Miller 2015; Johnson 2015), positioning them in what Diane Reay (2004) has called the "lumpen proletariat" of academia. Academic Diary is unlike any of these writings. Its power comes not from grand analyses or programmatic 
statements, but from something much quieter, more gentle, but no less subversive. Reading it was a profoundly moving experience that made me cry at times and laugh out loud at others.

Les's experience of "death by PowerPoint" offered one of the book's belly laughs, as he explained how letting his children play on his laptop one weekend resulted in a family photos screensaver kicking in part way through a deadly serious conference presentation:

As I talked earnestly about the War on Terror and the London bombings the automatic slideshow treated the audience to a high-resolution sequence of holiday snaps of my family in various states of beach undress and my kids headbanging with guitars like extras from Jack Black's movie School of Rock (2016:61).

Who cannot imagine how excruciatingly embarrassing it must have felt when he realized? Yet, almost as funny is that fact that no one in the audience remarked on it! Perhaps, they were being polite? Perhaps, they saw it as some sort of ironic postmodern commentary? Finally, at the drinks reception afterwards, one delegate said "nice slideshow" and asked if the guitars were Les's own. Only in academia, eh! Academic Diary is replete with astute observations about homo academicus and has a keen eye for the absurd: the conference etiquette, the ludicrous pomposities, and the search for spaces that do not have wifi so we can "disconnect" for a while. It is a joy to read, with only the mildest of criticism reserved for the worst of academics' vanities and self-importance. Like a really good novelist or film director, Les has paced the diary brilliantly so that moments of hilarity are balanced by serious reflection, and the times when I had a lump in my throat are swiftly leavened by comical observations-like the dead rat in Laurie Grove (a Goldsmiths thoroughfare), or the nightmare of exam invigilation with traffic noise, police helicopters, and an opera singer rehearsing next door.

I carried Academic Diary in my head and my heart for several days before beginning to write about it. There is so much here it feels like it is overflowing inside me. I have talked about it compulsively with my dear friends Gail Lewis and Shani Orgad. In contrast to Les Back's admirable brevity, I fear that if I begin to open up all the questions, thoughts, sorrows, pleasures, angers, reflections, and wistfulnesses that the book has provoked, I will never be able to stop. Mostly there is the anxiety about how to do justice to this "little big book" that exudes love and humanity. It is presented as light bites, as tapas, but it feels like a banquet: so full of ideas and insights and kindness, so nourishing in its generosity of spirit.

In the first part of what follows, I will try to highlight what I see as the most important themes and contributions of Academic Diary; and then, in the second to raise some questions and to think about how we might build on and take forward the projects of hope, social justice, and solidarity of which Academic Diary forms a part.

\section{Counting Versus Value}

Higher education is "being disfigured by cultures of audit and commercialisation," Les Back says at the start of this diary (2016:3). Indeed, as his former Goldsmiths colleague Roger Burrows (2012) has shown, British academics are now routinely assessed on more than one hundred indices and scales that measure academics' value and monetize them. These metrics rate our grant income, research excellence, citation 
scores, student evaluations, esteem indicators, impact factor, $\mathrm{PhD}$ completions, and on and on. They produce what I have dubbed the "quantified self of neoliberal academia" (Gill 2015) as academic labour is systematically reduced to "marketable outputs of a quantifiable nature". The injuries produced by this are manifold: on one hand, this counting culture fails to take into account those aspects of academic labour that are not amenable to measurement (Arrigoitia et al. 2015:190); on another, it strives to render everything quantifiable, calculable - as feminist geographers Klocker and Drozdzewski (2012) show vividly with their excellent intervention, "how many papers is a baby worth?" These metrics incite a regime of "document everything, reveal nothing" (Butterwick and Dawson 2005:55) and instigate a form of "punitive accountability" that is "undoing all things public" (Fine 2015). They produce what Chris Lorenz (2012) dubs "inner immigration"-which I understand (through my reading of Fanon) as a specific form of alienation from oneself in which the ability to hold a double consciousness - i.e. refusing to take on the university's way of seeing you and holding onto a separate/independent sense of one's own worth and value - is both essential, difficult, and agonizingly painful. As Canadian scholar Marc Spooner (2015:5) has put it: "Sometimes the antagonist isn't wielding a gun. In this kind of attack, there is no person or event that can be met head-on with a protest or a strike. There is no explosion, no great conflict, no epic battle. Such is the case with higher education's silent killer: the slow, incremental creep of audit culture."

Academic Diary stands against these processes - in fact, the entire book can be read as an indictment of them. But unlike the authors cited above, it does so not through documenting and critiquing the toxic effects of these "metric assemblages" (Burrows 2012) but, as I see it, by attempting to create - and indeed model — a radically different way of being and a new "structure of feeling" within the Academy. What Les Back shows is that the things we count are not the most important things. Time and again, as a motif throughout the book, he holds up for gentle mockery the supposed successes - the trinkets and baubles of academia - and juxtaposes them with what really counts (yet is not counted). A particularly caustic entry sees him discussing the New Year's Honours, as perhaps the apotheosis of a system preoccupied with hierarchy and reputation.

'Don't get me wrong', he says, 'I have nothing against rewarding citizens for good work - I understand why people who have run hospital trusts or musicians from the wrong side of the tracks are lured to accept an OBE. But for academics it seems they are simply status adornments like medals to be pinned after their name, perhaps alongside their British Academy Fellowship. Such baubles smack of an imperial melancholia that haunts British society and indeed university common rooms. How can any intellectual worth his or her salt accept an award that ends with the word 'Empire'? (page 88).

My sentiments exactly - and those of many scholars who have turned down such "honours." But Les Back does not leave it there; instead, he reminds us what things, by contrast, are worth valuing - above all, the difference we can make through teaching. Conversations with students, expressions of appreciation, moments when someone suddenly "gets it" or sees something in a new way-these are why higher education matters: "The finest reward any university teacher or academic could hope to receive." A letter from a student "is treasured beyond titles, honours, university research rankings or even scores in the national student survey" (2016:90). 


\section{Slow Academia}

Les Back's vision shares much with some of the current feminist writing about "slow academia". A feminist geography collective (Mountz et al. 2015) asks, "What if we counted differently? Instead of articles published or grants applied for, what if we accounted for thank you notes received, friendships formed, collaborations forged?" They continue: "Good scholarship requires time: time to think, write, read, research, analyse, edit, and collaborate. High quality instruction and service also require time: time to engage, innovate, experiment, organise, evaluate and inspire." Academic Diary reinforces this sentiment calling for us to "slow thinking down" and to resist the "overwhelming bureaucratic impulse to speed up academic production, and make academics into tacticians preoccupied with the game of professional standing" (2016:11). "Part of the point of academic metrics is to make us as employees feel like we are failing even when we are killing ourselves to succeed." (2016:173-4).

The speeding up and intensification of academic life produce what Kathleen Lynch (2010) has called care-less workers. Workloads are so heavy and expectations of productivity so high, she argues, that they can only be achieved by workers who have no relationships or responsibilities that might constrain their productive capacities. A growing body of work examines the difficulties of mothering whilst working as an academic (Meyers 2012; Mannevuo 2016), and a mushrooming self-help field and blogosphere gives advice on how to ensure that one's children do not "show" academically_one of Mona Mannevuo's (2016) interviewees memorably suggests that her maternity leave "looks like a criminal record on the CV." As Maria do Mar Pereira (2016) argues, not just parenting but also activism can be affected by thissqueezed out by the proliferating demands made of academics. She quotes Lauren Berlant saying that, "to have a life at all" in these circumstances increasingly seems like an accomplishment. This care-lessness also operates within Universities in the damage done to our ways of relating to one another such that colleagues become experienced as interruptions, and teaching as something to be avoided.

Against "fast academia" (Gill 2010) or, "academia without walls" (Gill 2010; Pereira 2016), there has been a growing interest in slowing down as a way of resisting the temporal logics of neoliberalism. Some sociologists interpret this slow movement critically, seeing in it a failure to recognize privilege and an attempt to mystify institutional hierarchy. In a much circulated public letter, Carrigan and Vostal (2016) critique the authors of The Slow Professor (Berg and Seeber 2016), calling into question the idea that academics are really so stressed and arguing that, "“slow professorship' only makes sense when such decelerating professors can take it for granted that junior associates will accelerate to pick up the slack." In my view, this is to misunderstand the notion of slow scholarship - at least in its radical versions - which repeatedly emphasize that the "slow" in slow scholarship is not just about time but about structures of power and inequality" (Martell 2014, emphasis mine). Mountz et al. (2015) underline that, "slow scholarship cannot just be about making individual lives better, but must also be about re-making the university" (ms 4). This emphasis comes across too in Academic Diary, albeit located in an exhortation to the individual: "to try to resist the temptation to think too fast and write too much, too quickly" (2016:11). It is hard to disagree. Yet, when all the structures of our institutions reward the exact opposite, how can we move this from an individual to a collective strategy and also address the social justice agenda that rightly informs Carrigan and Vostal's intervention: some and not others are better placed to adopt slowness as a mode of resistance and can do so with fewer penalties. 


\section{Respect: Listening and Speaking}

Not surprisingly for someone who has written a book entitled The Art of Listening (Back 2007), the ethics and politics of communication are at the heart of Academic Diary. The importance of curiosity inflects the entire book - an ethic in its own right, the absence of which signals not simply a closed mind, but the utmost disrespect to other human beings. Back quotes Simone Weil for whom the phrase "you do not interest me" is both a gross cruelty and an offence against justice. The biggest gift we can give to anyone, Back argues, is being interested and curious. The importance of listening attentively to others runs like a bass track through this book. It is hard to overemphasize its importance. He quotes John Berger: "Listening is what's important. Listening to a story is primary, the listening is always primary" (quoted on p74). It is at the heart of teaching, of researching, and of supervising PhD students: "You listen to them, you care about them... You give them time. You say the difficult things if you have to," he says, quoting his own supervisor Pat Caplan (Back, 2016:160).

Listening is also part of the space of open debate that should be cherished within Universities - for all their flaws, including the persistence of racism and of tenacious class divisions. But Universities for Les Back are still spaces of "vital and productive diversity" (2016:8), communities of dissensus, in Bill Readings' term, which "drive us to think harder about the key issues and problems of our time" (2016:8). Goldsmiths is clearly beloved by Back as one of these sites, along with other spaces such as public libraries, movingly defended as they are attacked by successive right wing governments. I was deeply affected by Les Back quoting Toni Morrison's view of libraries as places that stand alone in offering free access to knowledge but also as refuges, truly open spaces for life in public: "No tuition is charged, no oath sworn, no visa demanded" (Morrison 2013, quoted p.196; see also Angela Davis and Toni Morrison, Live from the New York Public Library, October 27, 2010). He writes: "This openness conveys to all in society a message that, in her words, says: 'touch me, use me, my hush is not indifference, my space is not a barrier'" (Morrison, quoted in Back, 2016: 196).

I also love the sense of Universities as populated and run by many, many people besides academics. Involved in the Justice for Janitors campaign several years ago, and being part of a movement to persuade my own University to pay the London Living Wage to its cleaners and catering staff, it was wonderful to see how Les Back's ethics of listening extended to porters, gardeners, security guards, and administrators: "Without them," he comments acerbically, "there would be no University. Academics would have nowhere to teach their students or return to from their adventures on the frontiers of knowledge." Meanwhile, many such workers feel patronized or mocked by academics - not worthy of the interest or curiosity that radiates from Les. I recently wrote an impassioned plea (Gill 2017) for academics to take seriously "other precarities" within the University -for example those of the legions of workers now hired on sub-contracts, often, troublingly, by companies, such as Group 4, that are deeply enmeshed in the carceral system - no longer even direct employees of the University. Then along comes Les Back, who in his open, curious, humane way instantiates in his very being everything I tried - in longform and much more clumsily - to argue.

Speaking as well as listening is important. Academic Diary starts with a letter to an imagined new student. "Listen but don't be silent," advises Les. "[D]on't be silenced by the authority structure of the lecture hall. There is no such thing as a foolish question" (2016:19). Speak out, too, against the racism that still corrodes Universities, Back argues: "It needs to be acknowledged that racism has done damage to reason, done damage to academic and civic freedoms, and has done damage to the project of education itself” (2016:143). In Les's writing 
about "the sheer weight of whiteness that bears down on the academy", I am reminded of Ruth Frankenberg's (1993) work on what it means for white people — such as Les and I - to take seriously our power and privilege in order to contribute to anti-racist struggles. Like Frankenberg (and Vron Ware with whom Les has also written critically about whiteness [Ware and Back 2002]), for Les Back, denial is not an option, but nor too is its converse, the kind of mesmerism of white guilt, with its paralyzing qualities and tendency — paradoxically— to once again recentre whiteness, like a permanent Whites Anonymous meeting: "Hi. My name's Les. I am a recovering white person" (2016:143). Instead, what is needed is a "troublesome and uncomfortable" reflexivity, an "on-going questioning that strives to step out of whiteness's brilliant shadow" (2016:143).

Listening, staying silent, speaking out: all are ethical acts. For Back, implicitly, communication must be accessible, and be inclusive; it must try to reach out to people, not exclude them. The deliberate obscurantism of much academic writing cannot be ignored, as critiqued by bell hooks and many others: "It is sadly ironic," hooks wrote in Yearning: Race, Gender and Cultural Politics, "that the contemporary discourse which talks most about heterogeneity, the de-centred subject, declaring breakthroughs that allow recognition of Otherness, still directs its critical voice primarily to a specialised audience that shares a common language rooted in the very master narratives it claims to challenge" (1990:25). Instead, in Academic Diary, we have a beautiful, clear, open style that invites all in, that allows us to participate, that welcomes questions. The medium and the message here are intimately related.

\section{Thinking Together: Hope, Generosity, Solidarity}

In the glowing endorsements that accompany Academic Diary are several that highlight the "comfort" offered by this book - its compassion and supportiveness. It is "like having an academic mentor in your pocket," comments David Beer, observing that many will feel the need to keep it near them at all times. This resonated so deeply with me that it provokes tears, even now, sitting in front of my keyboard, several days later. The word "comfort" is not one that appears in academic journals very often, and far less in book reviews. It points to the singularity of this book. It should make Les Back feel very proud. He has argued that "[m]ore than any other measure the value of what writers do, even academic ones, is to provide companionship for further thought" (2016:64). His book does this: it befriends its readers; it will make many of us feel a little less alone; it offers resources for hope and a different vision of the University.

What then are these resources? As Les Back acknowledges, they are not laid out programmatically, but are "hidden in the detail of each of the entries" (2016:11). I think they are to be found in the ideas I have tried to bring out in this essay; at root, they are about valuing things differently. They are about resisting the regimes of value that define the neoliberal University; about listening and care and respect; and above all about kindness and generosity. They are less to be found in grand political gestures than in a coherent personal ethics - they are in the decision not to retain one's anonymity when reviewing a paper for a journal, in the particular emotional texture of an exchange in a $\mathrm{PhD}$ supervision, in the care taken to respond to an email from an A-level student. In upholding the importance of hope, he argues that to resist we as individuals have to "loosen the grip of self-regulation and act differently" (2016:11).

I recognize this injunction as part of a long tradition of anarchist, feminist, and socialist thought and action. Rather than waiting for some glorious day on which barricades are stormed 
and revolution occurs, this body of radical thought attempts to bring what Spanish revolutionaries in the 1930s called "the new world in our hearts" into being, here and now, by prefiguring in small but important ways the just society we want. The sentiment is now captured in a multiplicity of "inspirational" media forms (greetings cards, T-shirts, social media skins and walls) that exhort, apparently after Gandhi, "be the future you want to create". I like this emphasis in many ways (though not all). I try to live my life-inside and outside academia - in this way too, striving to listen to, support, and care for others; living within an increasingly brutal neoliberal capitalist regime but living by a set of values that is dissonant and holds other things dear, including other ways of relating. But is that enough? Will such actions truly offer significant resistance to the forces that are disfiguring life within Universities (to say nothing of beyond)? We know from history that "all that is needed for evil to triumph is for good people to do nothing." But is the obverse necessarily true, that by living a "good" ethical life one can halt the poisonous and corrosive march of neoliberalism, as it disseminates the model of market competition to every sphere of life?

These are, of course, huge questions - far too big to be answered in this essay, and neither fair nor appropriate to lay solely at Les's door. Indeed, the gift of his book is that it provokes such interrogations. But these are questions for all of us. I am asking them of myself as much as anybody else, for they are about nothing less than the kind of world we want and how to bring it into being. In my remaining space, I push at these and other questions raised for me by reading Academic Diary.

\section{Where Is the Pain?}

Les and I share a great deal. We are both white, British sociologists. We are the same generation, just a few years apart. We both occupy senior, privileged positions within London Universities and indeed both work within small relatively marginalized colleges of the University of London - late adoptees, and in the case of City, a brand new member of the "club." But the similarities do not end here. Importantly, in both cases, our intellectual and political formations have been profoundly shaped by Stuart Hall-honoured in Academic Diary in a wonderful chapter titled "What Would Stuart Hall Do?" More broadly, of course, we are both left wing, critical scholars with significant interests in thinking sociologically about what is happening to and in Universities. I was aware of these - really quite striking biographical overlaps before I started reading Academic Diary, but by the end of it, I had identified another powerful similarity: a tendency perhaps towards romanticism and emotionality.

Maybe that is why I feel that I really "get" Academic Diary, and why reading it was such an intense experience. It was redolent of being in a state of heightened emotion-falling in love or grieving, for example - when one apprehends the world so intensely, one feels stripped of several layers of skin, and when sounds, colours, and tastes are suddenly amplified. I think this is also the gift of Les Back's writing: his ability to elevate the humdrum and routine into something special. Reading Academic Diary felt like someone had sprinkled fairy dust onto my life; everything had a new shine and lustre. There is something almost ennobling about the book. In answering the question of why higher education matters, he makes one feel that our work-and above all our teaching - is a truly noble profession. This alone, when so many of us feel so attacked, so surveilled, so devalued, is an extraordinary gift. 
But where, I wondered, amidst this elegiac portrait, is the pain of contemporary academic life? No one, and last of all me, wants to exaggerate this suffering or to engage in some narcissistic project of self-indulgence when there is true agony in the world - we are not in Sudan or Syria, we are not being tortured, we are not putting our children in unsafe vessels to try in desperation to make it to European waters. But nevertheless there is significant suffering in academia that cannot and should not be ignored, and especially not by those of us who are privileged and therefore, in my view, have an extra obligation to speak out. Some of this is the suffering of the vast intellectual precariat who now constitute the majority of academics - on short term, temporary, unstable, contingent contracts, or often no contracts at all-representing what Ruth Barcan (2013) has described as "an intellectual and social catastrophe masking as flexibility." But it is also the pain of academics who do have security of tenure: people nevertheless pushed to breaking point by impossible workloads; people perpetually on the edge of total collapse: people whose existence is defined by an excoriating anxiety, who dread every new research assessment or teaching feedback, who feel themselves to be hanging by a thread or clinging on by their fingernails. As I noted recently (Gill 2017), academics' talk about our own lives has become suffused with extraordinarily violent metaphors: people speak of going under, of coming up for air, of drowning or suffocating. This shocking imagery should surely give cause for concern.

In the 6 years since my article "Breaking the silence: The hidden injuries of neo-liberal academia" (Gill 2010) was published, I have received two or three emails every single week from people telling me how and why they have been touched by it. Many of these were expressions of gratitude and relief that they no longer felt so alone or "the only one who felt like this." Many others are accounts of terrible unhappiness, mistreatment, insecurity, and fatigue. My archive of letters and emails now runs to nearly 2000 items of correspondence; a veritable catalogue of tales of toxic experiences within the neoliberal University, which underscore my sense of the profound, affective, and somatic crisis confronting us. Others are writing of this too. Plan C (2015) argue that "Today's public secret is that everyone is anxious...It has become the linchpin of subordination." Ann Cvetkovich (2012), in turn, writes powerfully about her depression as a "public feeling" that circulates through academia. Pereira (2016), after interviewing scholars in Women's, Gender and Feminist Studies, in 2007/ 8 and again in 2015/6, concludes that things have become immeasurably worse for academics in those 7 years:

It is no longer a (thinly veiled) secret that in contemporary universities many scholars, both junior and senior, are struggling - struggling to manage their workloads; struggling to keep up with insistent institutional demands to produce more, better and faster; struggling to reconcile professional demands with family responsibilities and personal interests; and struggling to maintain their physical and psychological health and emotional wellbeing. (2016:100).

This sense of crisis now pulses through social media as well as through cries of pain on sites like The Guardian's Academics Anonymous - exploring and documenting the injurious conditions of being University workers. Yet, this pain is not really to be found in Academic Diary, whose affirmative emphasis is foremost. I wonder if this was a choice? I recall the comments of journal editors who have treated my own articles as a "moan" or a "whinge," not a sociological/psychosocial intervention (as I naively like to consider them). How, I wonder, might we think together both the importance and pleasures of academic labour alongside its many injuries? 


\section{Bad Affect}

I remember once reading a definition of postcolonial criticism which described it as like being a "party pooper" since its aim is to trouble, upset, and interrupt the (epistemic) violence of colonialism (Ang 2001). No one is going to be happy when the said party pooper arrives, because she is going to bring the whole thing down and make people feel bad. (Enter: Ros) Bringing pain and injury to the fore in this discussion makes me feel similarly — or perhaps also like the "feminist killjoy" so eloquently discussed by Sara Ahmed (2010). I experience myself (now and regularly) as breaking what Arlie Hochschild (2003) calls the "feeling rules" of academia when I do not participate in the pretence that everything is alright. Last week, I was her when I contributed to a staff "away day" discussion of "ideas for new MAs" with the reflection that, whilst in theory I might have multiple ideas for wonderful master's courses, I felt that I and most of my colleagues were barely surviving as it was. I noted (the unspoken fact) that two out of ten of our team were on long-term sick leave and had not been replaced (even though one had been absent for over a year) and suggested that we could not possibly do more than we were doing. The MA ideas were shelved. I felt a bit low afterwards; maybe I had dented some real enthusiasm. Party pooper/killjoy indeed! But then two new early career colleagues emailed me and thanked me profusely for saying what they did not feel confident articulating.

One of the things I loved about Academic Diary, then, is its emotionality. Unlike so much in contemporary academia, it is not afraid of emotion. Feelings and sentiment emanate from every page. Social justice here is not just a concept, an ethic, or an ideal, but it is also lived in feelings, something that is desired and longed for. It reminded me of Robin Morgan's (1971) poem Monster, which I read first in the 1980s when I was becoming a feminist, and at the same time becoming captivated and intoxicated by amazing poetry that was so different from what we learned in school. She writes:

I want a women's revolution like a lover.

I lust for it, I want so much this freedom,

this end to struggle and fear and lies

we all exhale, that I could die just

with the passionate uttering of that desire.

I know from Academic Diary that Les Back desires a more just world in exactly this embodied, passionate way. His politics go "all the way down," as we used to say, pointing out the difference between those whose commitment to social justice felt deep and authentic, and those for whom it seemed to remain on the surface. Yet, the affect that animates Academic Diary is, for the most part, overwhelmingly positive and even noble. In the world conjured by this diary, love and generosity and kindness and solidarity are to the fore - and boy, this is wonderfully moving and affirming as I have said! But where are the other, less palatable, affects and behaviours? Where is the envy, the rage, the nastiness, the bullying, the bad behaviour, the competitiveness, the mean-spiritedness, the colleagues who dump on others, the people who just do not reply? It is not just that the pain and hurt of academic life seems absent, then, but also that much of the difficulty and messiness of academia is missing too. Cruelty is mentioned occasionally in passing and on one occasion Les Back comments, "[a]cademics are not always very likeable" (2016:16) but this is as far as he goes. In the stories and accounts that are most vividly presented through the book, people are fair, dignified, and, often perhaps, viewed through a rosy glow. They are students who write thank you letters, and colleagues 
who exemplify the most generous ways of relating. Racism and classism are conjured as problems throughout the book, but they are rarely located in individual behaviours or actions or specific challenging situations. I understand the constraints of the diary format and the difficulties of protecting anonymity and so on, but I missed some of the "bad affects" of academia, not least because I want to know "what Les Back would do?" - as someone I admire immensely — when confronting the mess and struggles of academia that I seem to confront on a daily basis, in a world where some people are sexist and homophobic, others are insecure and vicious bullies, where meetings can feel like battlefields, when sometimes students "punish" lecturers, where micromanagement and surveillance can ruin all the joy of something, and where hearing the results of research grant applications can destroy a colleague's sense of self-worth.

\section{Love and Vocation}

One of the other enduring ideas that runs through Academic Diary is the conviction that being an academic is not simply a job but something more, a calling. Back quotes Edward Said, in his 1993 Reith lectures, warning of the dangers of "professionalism": "[T]hinking of your work as an intellectual as something you do for a living, between the hours of nine and five" (Said, quoted on page 117). Against this, Les Back argues for more risk-taking and adventurousness to expand what can be thought and said, but also "to see that what we do is not just a job but an intellectual vocation or craft" (2016:11). I have some sympathies with the sentiment that I imagine lies behind this argument, and its resistance to imperatives of narrowing, marketization, and commodification. But it seems to me an odd target for contemporary critique. In the months before Academic Diary was published, two major surveys of British University life were published: one by the Times Higher Education, and the other by the UCU. Their accounts of academics' lives were strikingly similar: conveying a picture of a profession overworked to the point of mental and physical collapse. Far from doing a "nine to five," treating their work in a "jobsworth" manner, academics were revealed in UCU's (2016) survey of 12,000 people, to be working on average 13.4 extra hours every week-with senior academics doing significantly more. To put this another way, academics are working for free for two extra days per week - that is, working the equivalent of a 7-day week every week. The 2016 University Workplace Survey, conducted by the Times Higher Education, furnishes free comments that translate these figures into reality, and make sobering reading:

I feel unappreciated - I work 100 hours a week and I'm exhausted.

I thought this was my dream job... but the workload is unmanageable.

I don't think I can realistically keep this up until retirement without making myself seriously ill from stress (cited in Grove, 2016).

It seems to me that many academics are already deeply invested in notions of vocation, and we often provide extraordinary care and support for our students - perhaps especially female academics who take on the vast majority of pastoral care and do the "housework of academia" (Brabazon 2014; Leathwood and Read 2012). Many of us suffer deeply because we do live up to this ideal-we spend lots of time with students, we look at draft after draft of dissertations, we stay up all night to write references for students and colleagues, we review generously for journals - and sometimes, after all of this, completely exhausted, there is nothing left for ourselves, and nowhere to turn for support, and it is usually at those moments that your HoD 
says, "why haven't you published in any top ranked journals this year?" (see Gill and Donaghue 2016 on feminist blogs which discuss this; see also Pereira 2016). Many of us also suffer when we cannot live this vocational ideal. As one lecturer wrote in a moving blog for The Guardian: (May 20, 2016) "Dear student, I do not have time to mark your essay properly... In an ideal world your work would be read by an enthusiastic engaged professional, but the reality is very very different." Such accounts hint at the huge personal frustrations and disappointments experienced by academics, and the very particular forms of alienation that accompany not simply being stressed but also feeling unable to carry out one's job as one believes it should be done.

Against this context, stressing the need to see academia as vocation and calling seems a strange choice. On the one hand, it captures something real about our passionate attachment to our work, which is palpably different from many other jobs (though by no means all-think of medicine, journalism, social work, NGOs, cultural and creative industries, schools). On the other, like exhortations to "do what you love," it can so easily become a disciplinary mechanism, a way of extracting yet more work from us at intense personal cost. Andrew Ross calls this "sacrificial labour" - underpaid and exploited because the reward is supposed to be intrinsic - we are "called to our art" or our intellectual work. I have discussed this previously (Gill 2010) drawing on Lauren Berlant's (2011) notion of "cruel optimism." Mona Mannevuo (2016) expresses it beautifully when she says, "contemporary academic capitalism works through affects and languages of love, flexibility, and productivity." She talks about us being "caught in a bad romance" " with academia - it is not just like a difficult relationship, it is a bad relationship, and one profoundly marked by gender, considering the associations of unpaid labours of love with women. How do we resist this? How do we remake this relationship? The Italian autonomists call for outright "refusal" (Weeks 2005). Our Union tells us to "work to contract." Our occupational health and counselling departments exhort us to become "resilient." Our blogosphere endorses a kind of "reluctant individualism." Our selfhelp books and apps suggest mindfulness training and self-care. Academic Diary, by contrast, celebrates our elevated sense of vocation. I think it is genuinely hard to know how to proceed: how to resist, how to take care of ourselves and each other in all of this (see also Res-Sisters 2016; SIGJ2 Collective 2012).

\section{Conclusion: If Generosity Were Enough}

One of the enduring themes of my own research-including my writing about the University-has been to challenge the persistence of individualism as a way of organizing and accounting. The Hidden Injuries sought not to simply highlight the silenced and difficult aspects of academics' experiences and to render them knowable and speakable (Tuck, 2015), but also, crucially, to expose the extent to which these experiences are lived through a poisonous individualizing discourse. What I have been struck by, again and again, in conversations with academics is the dominance of an individualistic register - a tendency to account for ordinary experiences in the academy through discourses of excoriating self-blame, privatized guilt, intense anxiety, and shame.

Academic Diary interrupts this toxic individualism with a thorough-going sense of the value of the sociable and convivial features of academic life, a clear focus on what really matters, and above all, a benign and principled focus upon generosity as a way forward. As Les Back notes, this should not be misunderstood as just a matter of "being nice to others" 
(2016:114). It is much more than this. He talks about generosity as nothing less than a "survival strategy," "a prophylactic against the corrosive aspects of intellectual cruelty" that have become institutionalized. "Try it," he urges. And I hope people will. But it led me to a small thought experiment in which I tried to imagine a utopian academia where everyone had taken up this challenge, where everyone was as lovely as Les, if you will. Would that be sufficient to resist the destructive transformations that are disfiguring Universities, the neoliberalism that is attacking "the principles, practices, cultures, subjects, and institutions of democracy" itself (Brown 2015:9)? To what extent can personal actions - even enacted by many individuals - offer a real challenge to the structural forces ranged against us? Is individual generosity a powerful enough tool to fight systemic meanness and brutality? In short, is living a "good life" within academia enough?

Les Back has written a wonderful book. In provoking the questions I raise here-and doing so much else besides - he offers us a precious gift and an opportunity to reflect upon who we are, why what we do matters, and who we want to become. Academic Diary is, to coin a phrase, a book that is almost impossible not to love.

Acknowledgements I would like to thank my dear friends Gail Lewis and Shani Orgad for their insights and encouragement whilst I was writing this piece.

Open Access This article is distributed under the terms of the Creative Commons Attribution 4.0 International License (http://creativecommons.org/licenses/by/4.0/), which permits unrestricted use, distribution, and reproduction in any medium, provided you give appropriate credit to the original author(s) and the source, provide a link to the Creative Commons license, and indicate if changes were made.

\section{References}

Adsit, J., et al. (2015). Affective activism: Answering institutional productions of precarity in the corporate university. Fem Form, 27(3), 21-48.

Ahmed, S. (2010). The promise of happiness. Duke University Press.

Albom, M. (1998). Tuesdays with Morrie: an old man, a young man, and life's great lesson. Hodder.

Ang, I. (2001). On not speaking Chinese: living between Asia and the West. Routledge.

Arrigoitia, M. F., et al. (2015). Women's studies and contingency: between exploitation and resistance. Feminist Formations, 27(3), 81-113.

Back, L. (2007). The art of listening. Berg.

Bailey, M., \& Miller, S. J. (2015). When margins become centred: black queer women in front and outside of the classroom. Feminist Formations, 27(3), 168-188.

Ball, S. J. (2000). Performativities and fabrications in the education economy: towards the performative society? The Australian Educational Researcher, 27(2), 1-23.

Barcan, R. (2013). Academic life and labour in the new university: hope and other choices. London: Ashgate.

Berg, M., \& Seeber, B. (2016). Slow professor: challenging the culture of speed in the academy. University of Toronto Press.

Berlant, L. G. (2011). Cruel optimism. Duke University Press.

Blackmore, J., \& Sachs, J. (2000). Paradoxes of leadership and management in higher education in times of change: some Australian reflections. International Journal of Leadership in Education, 3(1), 1-16.

Brabazon, T. (2014). "Maybe he's just better than you": Generation X women and higher education. Journal of Women's Entrepreneurship and Education, 3-4, 48-70.

Brown, W. (2015). Undoing the demos: neoliberalism's stealth revolution. MIT Press.

Burrows, R. (2012). Living with the h-index? Metric assemblages in the contemporary academy. The Sociological Review, 60, 355-372.

Butterwick, S., \& Dawson, J. (2005). Undone business: examining the production of academic labour. Women's Studies International Forum, 28(1), 51-65.

Carrigan, M. \& Vostal, P. (2016) 'Against the slow professor' https://markcarrigan.net/2016/04/13/against-theslow-professor/ accessed July 122016. 
Collini, S. (2012). What are universities for? Penguin UK.

Cvetkovich, A. (2012). Depression: a public feeling. Durham: Duke University Press.

Edu-Factory Collective. (2009). Toward a global autonomous university, cognitive labor, the production of knowledge, and exodus from the education factory. Autonomedia.

Evans, M. (2004). Killing thinking: death of the university. Bloomsbury Publishing.

Fine, M. (2015) "Troubling calls to "evidence": punitive accountability, disruptive innovation and neoliberal blues in the education deform project' paper presented at Public Engagement and the Politics of Evidence, July 23-25 University of Regina, Saskatchewan.

Frankenberg, R. (1993). White women, race matters. University of Minnesota Press.

Gill, R. (2010). Breaking the silence: the hidden injuries of the neoliberal university. In R. Ryan-Flood \& R. Gill (Eds.), Secrecy and silence in the research process: Feminist reflections (pp. 228-244). Abingdon: Routledge.

Gill, R. (2015) 'The quantified self of academia' paper presented at Public Engagement and the Politics of Evidence, July 23-25 University of Regina, Saskatchewan.

Gill, R. (2017) Beyond individualism: the psychosocial life of the neoliberal university.

Gill, R., \& Donaghue, N. (2016). Resilience, apps and reluctant individualism: technologies of self in the neoliberal academy. Women's Studies International Forum, 54, 91-99.

Grove, J. (2016) The University Workplace Survey 2016: results and analysis. https://www. timeshighereducation.com/features/university-workplace-survey-2016-results-and-analysis published and accessed Feb 42016.

Gutiérrez y Muhs, G, Niemann, Y. F, González, C. G., \& Harris, A. P. (2012). Presumed incompetent: the intersections of race and class for women in academia.

Halffman, W., \& Radder, H. (2015). The academic manifesto: from an occupied to a public university. Minerva, 53(2), 165-187.

Hochschild, A. R. (2003). The managed heart: commercialization of human feeling. Univ of California Press.

Johnson, M. L. (2015). 'Les be honest: Queer feelings about women's studies at a public regional university in the southeastern United States. Feminist Formations, 27(3), 237-260.

Klocker, N., \& Drozdzewski, D. (2012). Commentary. Environment and Planning A, 44(6), 1271-1277.

Leathwood, C., \& Read, B. (2012). Assessing the impact of developments in research policy for research on higher education: an exploratory study.

Lorenz, C. (2012). If you're so smart, why are you under surveillance? Universities, neoliberalism and new public management. Critical Inquiry, 38, 599-629.

Luka, M. E., Harvey, A., Hogan, M., Shepherd, T., \& Zeffiro, A. (2015). Scholarship as cultural production in the neoliberal university: working within and against 'deliverables'. Studies in Social Justice, 9(2), 176-196.

Lynch, K. (2010). Carelessness: a hidden doxa of higher education. Arts and Humanities in Higher Education, $9(1), 54-67$.

Mannevuo, M. (2016). Caught in a bad romance? Affective attachments in contemporary academia. In The postFordist sexual contract (pp. 71-88). UK: Palgrave Macmillan.

Martell, L. (2014, September). The slow university: Inequality, power and alternatives. In Forum Qualitative Sozialforschung/Forum: Qualitative Social Research (Vol. 15, No. 3).

Meyers, M. (Ed.). (2012). Women in higher education. New York: Hampton Press.

Mountz, A., et al. (2015). For slow scholarship: a feminist politics of resistance through collective action in the neoliberal university. ACME, 14(4), 1235-1259.

Murgia, A., \& Poggio, B. (2010). The precarisation of research careers: a comparative gender analysis. London: Routledge.

Nash, J., \& Owens, E. (2015). Institutional feelings: practicing women's studies in the corporate university. Feminist Formations, 27(3), vii-vxi.

Pereira, M. d. M. (2016). Struggling within and beyond the performative university: articulating activism and work in an «academia without walls». Women's Studies International Forum, 54, 100-110.

Readings, B. (1996). The university in ruins. Cambridge: Harvard University press.

Reay, D. (2004). Cultural capitalists and academic habitus: classed and gendered labour in UK higher education. Women's Studies International Forum, 27, 31-39.

Roggero, G. (2011). The production of living knowledge: the crisis of the university and the transformation of labor in Europe and North America. Philadelphia: Temple University Press.

Ross, A. (2014). Creditocracy and the case for debt refusal. New York: OR books.

Shore, C. (2008). Audit culture and illiberal governance: universities and the culture of accountability. Anthropological Theory.

SIGJ2, \& Collective, W. (2012). What can we do? The challenge of being new academics in neoliberal universities. Antipode, 44(4), 1055-1058. 
Slaughter, S., \& Leslie, L. L. (1997). Academic capitalism: politics, policies, and the entrepreneurial university. Baltimore: Johns Hopkins University Press.

Smiley, J. (1987). The age of grief: stories and novellas. New York: Alfred Knopf.

Spooner, M. (2015) Higher education's silent killer. Briarpatch Magazine https://briarpatchmagazine. com/articles/view/higher-educations-silent-killer accessed October 162015.

The Res-Sisters. (2016). I'm an early career feminist academic: get me out of here? In R. Thwaites \& A. GodoyPressland (Eds.), Feminist beginnings: being an early career feminist academic in a changing academy. Palgrave Macmillan.

Tuck, E. (2015) 'Biting the hand that feeds you: Theories of change in the settler state and its universities' paper presented at Public Engagement and the Politics of Evidence, July 23-25 University of Regina, Saskatchewan.

Universities and Colleges Union (2016) UCU Workload Survey https://www.ucu.org.uk/media/8196/Executivesummary_Workload-is-an-education-issue-UCU-workload-survey-report-2016/pdf/ucu_workloadsurvey_ summary_jun16.pdf. Accessed July 17th 2016.

Ware, V., \& Back, L. (2002). Out of whiteness: color, politics, and culture. University of Chicago Press.

Weeks, K. (2005). The refusal of work as demand and perspective. In T. S. Murphy \& A.-K. Mustapha (Eds.), Resistance in practice: the philosophy of Antonio Negri (pp. 109-135). London, Ann Arbor, MI: Pluto Press. 